UDC 81'36:81'366,581

DOI https://doi.org/10.32841/2409-1154.2019.42.2.15

Zhaboruke O.A., (1949-2019)

Grand Doctor of Philology, Professor

Zhaboruke I. A., Candidate of Philology (Ph.D), Associate Professor of the Germanic Philology and Methods of Foreign Languages Teaching Department South Ukrainian National Pedagogical University named after K. D. Ushynsky

\title{
PSYCHOGENESIS VERSUS ONTOGENESIS (COMMON AND PARTICULAR)
}

Summary. This article is dedicated to establishing of differentiated features of such closely related phenomena as psychogenesis and ontogenesis in the light of the suggested syntactic theory - the theory of logico-grammatical dynamics, proposed by O. Zhaboruke as an alternative to the existing universal grammars. As the main issues have already been highlighted in the previous publications, we will just recall that the essence of this theory is the attempt to explain the interrelationship between Thought and Language.i.e. we will focus on Factor 2 (F2), one of the basic principles of this theory. Thus, according to Factor2 the priority issues to be investigated are: which form of thinking is initial for psychogenesis and ontogenesis, and whether this or that form of thinking is primarily connected with matter or not.

There exists a considerable time lag between the process of the initial separation of thinking from organic matter and its final amalgamation (connection) with sound matter. Thus, slowness, great length in time of the action of Factor 2, the succession of duration of its phases, and also the time lag between the lasting of the latter - these are the determining features that characterise psychogenesis.

The crucial difference in the speed of development of the psychogenesis and ontogenesis can be explained by the fact that, behind the various qualities of the brain, the speech organs of the primitive man was only being formed, which demanded rather long period of time, while the baby has a perfect brain from birth. Under the conditions, stated above, the action of Factor2 in ontogenesis has its own specificity in comparison with psychogenesis.

So, we see that in the process of psychogenesis the formation of Factor 2 in the human brain is preconditioned by nature, which favoured the further mental evolution of the man and parallel formation of the natural language. As for the process of ontogenesis, unlike that of psychogenesis, it only makes use of Factor $\mathbf{2}$ in the process of assimilation of speech as the mechanism of this factor is inborn.

The article fills in the existing in present-day linguistics lacuna, as, to our knowledge, the problem of the detailed comparison of these phenomena on the level of neuroprocesses hasn't been tackled so far.

Key words: psychogenesis, ontogenesis, language, speech, thought, neroprocesses, brain, predication, predicativeness.

Formulation of the problem. More than once in linguistic literature we came across the statement about the close interconnections of psychogenesis and ontogenesis [1]. These statements, nevertheless, are mainly of common character, which proves that they are grounded more on intuition than any special study of the problem. The nature of differences and closeness between them hasn't been explained yet.

Purpose of the study. This investigation is aimed at the deeper penetration into the essence of these phenomena, and, by answering these questions, to fill in the gap which exists in linguistics, concerning these problems.

Theoretical framework. The starting point of this investigation is the theory of logico-grammatical dynamics which was proposed by 0 . Zhaboruke as an alternative to the existing universal grammars. As the main issues have already been highlighted in the previous publications [2], we will just recall that the essence of this theoryis the attempt to explain the interrelationship between Thought and Language, i.e. we will focus on Factor 2 (F2), one of the basic principles of this theory.This principle is decisive for the task set up in this article, so we will base ourselves on it.

Statement of the material. The essence of Factor 2 as we have already stated more than once, consists in simultaneous striving of Thought for amalgamation with Matter (without which it can't be expressed) and at the same time for separation from the latter in order to achieve lightness and dynamism [3]. (It's not by chance that in such fundamental disciplines as mathematics and physics symbols prevail. Being much lighter than words (materially) they secure necessary flexibility for the moment of thought. The same concerns the game of chess, in which symbols and formulae are used).

Thus, according to Factor 2 the priority issues to be investigated are: which form of thinking is initial for psychogenesis and ontogenesis, and whether this or that form of thinking is primarily connected with matter or not. In case of a positive answer, another question arises: what kind of matter it is connected with.

In psychogenesis as well as in ontogenesis, the initial form of thinking is predicativeness, the main features of which are: integrity, amorphousness, obscurity. Proofs to this are more than enough. Thus, particularly, if speech (language) is to be treated as the outer capsule of thought, then the speech of primitive people is similar to the speech of a child. In both cases, speech, like the form of thinking that generates it, is integral, amorphous and obscure. It is, first of all, the so called "holophrastic thinking" (the so-called "word-sentences") and interjections. Beside this we observe such 
non-verbal outer manifestations of predicativeness as gestures and the immediate reactions upon stimuli of the surrounding world as cry, laughter, moaning, shout, smile etc. Is predicativeness connected with matter? Undoubtedly it is - and tighter than ever. This form of thought is, in fact, nothing else but the functioning of the psychosomatic system (neuromatter) of a concrete individual itself. From here it follows that thinking is initially connected with organic matter into which it actually melts.

So, predicativeness - being the starting point of evolution - is one of those most important and earliest common features which are characteristic of both psychogenesis and ontogenesis. Another common feature, which is of no less importance, is the initial primitive connection of predicativeness with organic matter of a particular individual.

This primitive stage of evolution of thinking and its outer manifestation - speech (the language is out of question here at all) are only able to allow the animal-like level of "communication". With a primitive man it is, first of all, to draw attention of others to himself in case of danger, to warn them about danger, to show his satisfaction or dissatisfaction, etc. A baby while "communicating" with adults, means to inform his parents about his physiological requirements: hunger, the necessity to change his nappies, etc.

Amalgamated with organic matter, thinking is "heavy", inflexible, totally dependent on the latter: acuity of vision, hearing, quick response of a particular individual to various irritants. In slows down the "process of speaking" - the outer shell of thinking, makes it not quite clear to the addressee. That is why, according to Factor 2, thinking strives to separate itself from matter, to acquire lightness, agility. It is another feature which unites these two phenomena - psychogenesis and ontogenesis.

The main precondition for separation of thinking from organic matter is the cyclic nature of the Universe and its processes. It is laid down into the Universe by nature itself. "The Universe," - the wellknown linguist Jean Aitchison states - "stays in constant state of changes - the fact, which has been commented by philosophers and poets for ages" $[4 ; 3]$.

Thus, thinking under the influence of "everlasting wheel of changes" (E. Spencer) [ibid.] makes its first separation from matter - organic matter. The mechanism of separation in both cases - psychogenesis and ontogenesis - is the same. Under the constant periodic effect of certain chain of signals from the outer surrounding, in the human brain, figuratively speaking "bruises" are created, - and to be more exact, more or less constant algorythms of neuroprocesses, accompanied by chemical reaction. With time these algorithmic processes get rooted in the brain and begin their "independent life", which is manifested in their ability of selfactivation from time to time. It is manifested in the fact that" to bring into action" a certain neuroalgorythm, there is no need of a direct signal from the outside. An indirect signal is quite enough, but at times even such is not necessary. For example, feeling hunger or thirst - an indirect signal, - a certain "bruise" (neuroalgorythm) is automatically brought into action in the brain of a primitive man, and, as a result - a concrete image of something edible emerges (appears), though he has not anything like that before his eyes and so, it is impossible that it could affect his senses. As a result of such self-activation, a man can dream of some object (the prototype of the "bruise"), or even, just without any reason he can recall them. A striking example of existence of such "bruises" in the brain of a primitive man are paintings in deep dark caves, which archeologists find from time to time. The appearance of these first "bruises" in the brain of an individual (a primitive man or a baby) is nothing else but the first separation of thinking from organic matter - the abstraction of the first order. These so-called "bruises" ("brain corns") lay the foundation of memory.

Having separated itself from organic matter and worked out the net of independently functioning neuroprocesses of algorithmic character ("bruises" "images") thinking strives to amalgamation with matter again to lend these processes material embodiment. A man strives to share his mental experience with other people - his relatives or his fellow tribesmen.

As far as the net of "bruises" in a certain group of primitive people is, because of identical mode of life, almost similar, the search of matter is going on collectively, in the process of communication of primitive people among themselves. This search has been going on for thousands of years. The primitive man turns to the language of gestures, drawings, etc.

At last he chooses the sound matter as the most expressive and easy (his hands are free). The first words appear. Their appearance means nothing more than connection of thinking with sound matter. They reflect thinking on the level of images as having holophrastic character, that is the character of word-sentences.

So, both separation of thinking from organic matter - formation of independently existing first units of speech - images ("bruises") and amalgamation of the latter with a new type of matter - sound matter (in the form of the first holophrastic words)has lasted in the process of psychogenesis, as it has already been mentioned more than once, for hundreds and hundreds of years.

There exists a considerable time lag between the process of the initial separation of thinking from organic matter and its final amalgamation (connection) with sound matter. Thus, slowness, great length in time of the action of Factor 2, the succession of duration of its phases, and also the time lag between the lasting of the latter - these are the determining features that characterise psychogenesis.

The final choice of sound matter favoured the evolution and perfection of human organs of speech. As for the appearance of the first words, it opened the way to the deeper cognition of the surrounding world, and, on the other hand - to the further evolution of abstract thinking and, as a result, - formation of speech. Manipulating with words, connecting them together, substituting one word by another, the man could experience the resemblance and difference of things, which stood behind these words. As a result, there appeared classifications of words according to certain signs of similarity (likeness) or difference - a prototype of part of speech classification. As to ontogenesis, Factor 2 (this factor unites psychogenesis and ontogenesis) functions in quite different conditions. Not by accident that with the same mechanism, which is separation of thinking from and amalgamation with matter, in case of psychogenesis, hundreds of thousands of years precede appearance of first words, but in case of ontogenesis - that process is incomparably quicker - it lasts only about six or seven months. The first words, as it is well-known, are pronounced by a child at the end of the first year of life.

This, as we think, can be explained by several reasons. First of all by the character of "centrifuge" which conditions the separation of thinking fromorganic matter. In case of psychogenesis it is a whirlpool of natural phenomena - cyclic circulation of vital processes; (taking meals, alternation of rest and activities, sowing and harvesting, birth 
and death), change of seasons, of day and night, sunrise and sunset, phases of moon, etc. In case of ontogenesis these are cyclic processes of manipulations with a child, accompanied by speech. As we can see, in the first case, the cycles are extremely delayed, not focused on a particular individual, while in the other - they are accelerated, directed to a particular child. The difference of no less importance, is that in case of psychogenesis, the so called "bruises" are being formed in the brain of the primitive man mostly under the influence of visual signals from outside, though other types of signals also play important role in their forming. Such "bruises" we will name "visual bruises". In case of ontogenises the formation of "bruises" are mostly effected by speech which accompanies all the manipulations with a child. Sound matter is, as we have pointed out in the previous publications, is much more powerful than visual, so, there is no wonder that a baby forms "bruises" first of all of aural nature, while visual and other sensual components are only accompanying this process. The fact that these "aural bruises" are based on lexico-grammatical speech units, that have already been pressed into the brain (speech) of an adult. It means, however, that in the process of ontogenesis, sound matter must be found, polished in speech, while a child receives a ready product - natural speech, it only has to isolate them and assimilate through speech. It is clear, that in case of psychogenesis, voicing and articulating of the first "bruises" demands plenty of time, while in the process of ontogenesis it does not.

Another moment of no less importance, which conditions the difference between psychogenesis and ontogenesis is the organic matter of the brain itself from which thinking in the form of predicativeness strives to separate itself. The brain of the primitive man and the brain of a baby are two crucially different objects. If we turn to a metaphoric comparison, we can say that a brain of the primitive manwas like a hard rubber by its structure, while the brain of the baby is more like a soft porous sponge - with traces of one- million- and-a- half year's period of formation of "bruises". In other words, there is a mechanism of separating from matter and amalgamating with matter which has been stamped out from birth, which it can instantly reproduce under favourable conditions. It makes possible such quick assimilation of natural language in comparison of psychogenesis. N. Chomsky felt the in-born ability of the human brain to assimilate natural language but explained it by "in-born knowledge of deep language structures" [5, p. 32], which is not the same. In reality a child is not born with a knowledge of the language, its deep structures, it is born with a perfect instrument of acquiring this knowledge. The evidence of this, is the fact, that a baby, regardless of its race or nationality, is able to assimilate not only the language of his parents but any natural language, no matter how distant it may be from the language of his ancestors. Thus, in the process of psychogenesis, a man only creates, forms this mechanism, while in the process of ontogenesis he possesses it from his birth and uses it to assimilate speech.

The crucial difference in the speed of development of the psychogenesis and ontogenesis can be explained by the fact that, behind the various qualities of the brain, the speech organs of the primitive man was only being formed, which demanded rather long period of time, while the baby has a perfect brain from birth. So, anatomic and physiological state of organs of speech, their readiness for pronouncing sounds of various difficulties and sound chains, is also one of the factors which slows down the process of psychogenesis and, at the same time, speeds up the process of ontogenesis.
Under the conditions, stated above, the action of Factor 2 in ontogenesis has its own specificityin comparison with psychogenesis. Let us try to reveal the peculiarities of its action.

So, under the effect of speech centrifuge, which accompanies manipulations of a baby care (bathing, putting to bed, feeding, swaddling), petting, etc, the first sounds to be imprinted in the brain of a baby are stressed vowels (they are comparatively many). They form the so-called "bruises" (the aural images) of a certain specific situation. The rest of unstressed syllables of these often repeated phrases serve as a background, which, with a course of time, gradually, level by level, become absorbed by the "bruise". The "bruise" acquires more and more clearness, discreteness, approaching the qualities of the original phrase, which an adult says to a baby. As for the "visual component" of the "bruise", it plays a less important part in ontogenesis than in psychogenesis, as the sound matter, which effects the brain of the child is more powerful than light waves.(The primitive man at the earliest stages of psychogenesis did not experience such speech accompaniment and could not experience it, in principle, as speech was at the earliest stage of its formation). "Visual" component, alongside with other components of the "bruise", formed under the action of tactile, taste and smell factors, accompanying the aural "bruise" finally join it. These components as well as the aural one, have their "nucleus" and "peripherals". The "nuclei" grow with the course of time, absorbing the peripheral aspects, become clearer and, gradually, layer by layer, get absorbed by the main "bruise", forming a coherent whole. The child realizes and memorises both stressed and unstressed components of a phrase, as well as the real process which lies under it: the people, their movements, certain objects, etc.

The formation of the "bruise nucleus" led by the aural component means the first separation of thinking from organic matter. Alongside with this process, according to the requirements of Factor 2 the unification of newly-created "bruises" ("germs of imagination") with sound matter. The thing is that the child has the natural mechanism for that. Sound signals which enter the brain of the child through his ear and are scanned by the former, at the same time, affect the muscle's of the baby's organs of speechhis tongue, lips, vocal cords, etc., which are set in motion [9]. The movements of the baby's tongue, mouth, lips can be often observed from the first days of the child's birth. The child automatically and subconsciously tries to reproduce the liveliest and most powerful sound of the phrase addressed to him, which is, as it has already been mentioned, the stressed vowel. The moment when the baby more or less successfully and, what is most important, consciously has reproduced this sound to mark a certain situation, is the beginning of the sound registration of the "bruise", the beginning of assimilation of certain words, and later on - phrases as well.

As we have more than once mentioned, the period of assimilation of new words takes place in the first year of the baby's life and, what is really important, layer by layer. Beginning with the stressed vowel, stressed syllable and then - by doubling the syllables, a preword, (an articuleme) is being formed - the unit of the so called "holophrastic speech". The sound registration of the "bruise" is being formed in the brain of the baby layer by layer, as well as the "bruise" itself, becoming clearer and more discrete with every new phase. The child begins to pronounce the stressed sound in a phrase, and, later, realizing the difference in length of the phrase pronounced to it, andthe syllable just assimilated, the baby expands the length of the articuleme by doubling the latter. Thus the words 
of the "children's language", so well- known to each of us, appear: няв-няв, бу-бух, му-му, папа, мама, няня, баба, гав-гав, еtс. At that, according to investigations, the stage of doubling syllables is undergone by the child no matter what language he is trying to assimilate.

As we see, as the assimilation of new words by the child goes on not without difficulty, step by step, as well as not easily went on the process of creation of words by the man. In this with psychogenesis, the formation of a word (creation of lexical units) went in the direction from a primitive individual to a primitive speech community. Individuals (there might be a few of them) "offered" their sound variants to mark this or that object - a thing or a living being - (sound imitation played a crucial part in that process) [3] and launched (ran, started) them into speech, where they were tested ("processed" "bounced"). As a result one of the variants became adopted by the community, other variants were either rejected altogether or served as synonyms. As for ontogenesis, it moves in the opposite direction: from speech community to an individual (a baby). Lexical units of a certain language - the certain heritage (asset) of the whole speech community, gradually penetrate into an infant's brain (a concrete individual) in which they take roots and become individualized. These phenomena are subordinated to one of the main laws of dialectics, namely the law of unity of oppositions of the general and individual. This does not only prove the relationship of psychogenesis and ontogenesis, but also verifies (validates, confirms) the accuracy (validity, correctness) of the way to explain their essence (nature).

The process of assimilation of speech by the child has its difficulties as well. It is proved by the fact that a certain amount of children who began to communicate in their native language continue to mispronounce polysyllabic words for several years. They only pronounce one or two syllables distinctly - the stressed one and the one next to it, the rest pronounced rather unclearly. This indicates to a complicated character of assimilation words by the brain of a child, and individual functioning of Factor2 in every particular case.

Conclusions. Summing up the described above we reached the following conclusions: the relationship of psychogenesis and ontogenesis lies in their subordination to Factor2.

As for the difference between them we see it in the fact that the process of psychogenesis is the formation of Factor 2 in the human brain preconditioned by nature, which favoured the further mental evolution of the man and parallel formation of the natural language. As for the process of ontogenesis, unlike that of psychogenesis, it only makes use of Factor 2 in the process of assimilation of speech as the mechanism of this factor is inborn. At that, Factor $\mathbf{2}$ in the process of ontogenesis, as well as in the process of psycogenesis imposes mental development of the child: through it, through its functioning the child assimilates the language and through the language - the whole mental experience of the manhood accumulated in its centuries-long evolution.

\section{References:}

1. Белякова Л.И., Филатова Ю.О. Физиологические и психологические аспекты речевого психогенеза. Язык и сознание: психолингвистические аспектыл. Москва : Наука, 2009. 216 с.

2. Жаборюк О.А. Проблема психогенези крізь призму теорії логіко-граматичної динаміки. Мовознавство. 2009. № 6. С. 3-12.

3. Жаборюк О.А. Сутність проблеми онтогенезу (домовленнєвий та ранній мовленнєвий періоди): авторська інтерпретація. Мовознавство. 2014. № 5. C. 57-70

4. Aitchison Jean. Language Change: Progress or decay? Cambridge University press, 2002. Thirded. $266 \mathrm{p}$.

5. Chomsky N. Aspects of the Theory of Syntax.: Cambridge Massachusetts : M. I. T. Press, Massachusetts Institute of Technology, N.Y. 251 p.

Жаборюк О. А., Жаборюк I. А. Психогенез versus онтогенез (спільне та відмінне)

Анотація. Стаття присвячена встановленню спільних i відмінних рис у таких споріднених між собою явищ, як психогенез та онтогенез із позицій запропонованої О.А. Жаборюк синтаксичної теорії - теорії логіко-граматичної динаміки. Ця теорія націлена на 3'ясування сутності взаємовідношень між мисленням і мовою. Основна увага сфокусована на факторі 2 (F 2), сутність якого полягає в одночасному стремлінні мислення з'єднатися 3 матерією та відірватися від неї. Таким чином, згідно $з$ фактором 2 (F2) першочергові запитання, які стоять перед дослідником, такі: яка саме форма мислення є вихідною при психо- та онтогенезі та чи $є$ ця форма мислення первісно з'єднана з матерією чи ні. Між процесом первісного відриву мислення від органічної матерії та процесом остаточного об'єднання ії зі звуковою матерією є теж тривалий розрив у часі. Таким чином, уповільненість, часова тривалість дії фактору 2 (F2), послідовність проходження (протікання) його фаз, а також часовий розрив між протіканням останніх - це ті визначальні риси, які характеризують психогенез.

Отже, ми бачимо, що у процесі психогенезу формування Фактору 2 (F2) у людському мозку зумовлене природою, що спричинило подальшу розумову еволюцію людини і паралельне формування природної мови. Щодо процесу онтогенезу, то, на відміну від психогенезу, він лише використовує Фактор 2 (F2) у процесі асиміляції мовлення, оскільки механізм цього фактору є вродженим.

Стаття заповнює існуючу в сучасній лінгвістиці лакуну, адже досі, наскільки нам відомо, детального порівняння цих явищ на рівні процесів, що відбуваються у мозку людини, зроблено ще не було.

Ключові слова: психогенез, онтогенез, мова, мовлення, мислення, матерія, нейропроцеси, мозок, предикація, предикативність. 